\section{Determinants of Structure of Corporate Governance Disclosure in Portugal}

\author{
Vera Cunha ${ }^{1}$ \\ ${ }^{1}$ Instituto Politécnico de Coimbra, Escola Superior de Tecnologia e \\ Gestão de Oliveira do Hospital, Oliveira do Hospital, Portugal \\ Lúcia Lima Rodrigues ${ }^{2}$ \\ ${ }^{2}$ Universidade do Minho, Escola de Economia e Gestão, Braga, Portugal
}

Received on

$01 / 29 / 2017$

Approved on

02/05/2018

\section{Responsible editor:}

Prof. Dr. Eduardo Contani

Prof. Dr. João Maurício

Evaluation process:

Double Blind Review

\begin{abstract}
Purpose - This study analyses the determinants of the level of corporate governance disclosure (CGD) by Portuguese companies listed on Euronext Lisbon between 2005 and 2011.

Design/methodology/approach - Using content analysis, we construct a corporate governance index for each firm based on the data extracted from the firm's corporate governance and annual reports. An ordinal logistic regression model is used to examine the relationship between the level of CGD and its determinants.
\end{abstract}

Findings - The empirical evidence suggests that foreign investor ownership, board size, board independence, external audit quality and degree of internationalization had a significant and positive influence on the corporate governance disclosure level, whereas ownership concentration, unitary leadership structure and debt had a significant and negative influence on corporate governance disclosure. No results were observed for board of director ownership and manager stock option compensation variables.

Originality/value - This study extends the previous literature by examining corporate governance disclosure. Moreover, it extends prior work by analysing foreign investor ownership, manager stock option compensation and degree of internationalization as determinants of information disclosure. Finally, we believe that this study, conducted over a longer period of time, might give us stronger statistical evidence.

Keywords - Corporate governance, disclosure index, consolidated annual reports, Portugal.

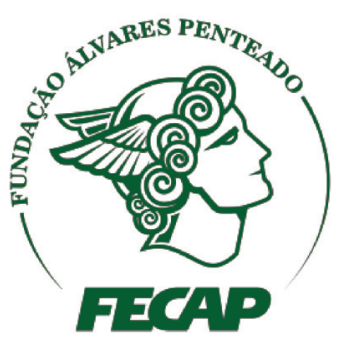

Review of Business Management

DOI: $10.7819 /$ rbgn.v0i0.3359 


\section{Introduction}

Corporate Governance is the main focus of our investigation and it is assumed that disclosure is crucial for the proper functioning of a firm's corporate governance structure. Corporate Governance comprises "a set of internal and external control mechanisms that reduce the conflicts of interest between shareholders and managers, arising from the separation of ownership and control" (Berle and Means, 1932, p. 396), including instruments designed to evaluate and hold managers responsible for their performance and management. A lack of corporate governance mechanisms and controls allows managers to deviate more easily from shareholder interests.

In recent years, the subject of corporate governance has generated much debate. The main interventions in corporate governance matters have been a reaction to crisis situations, seeking to restore trust and confidence in the markets. In the United Kingdom, the Cadbury code (1992) was the response to a number of corporate and financial scandals that occurred in the late 1980s, such as the Guinness scandal. In Continental Europe, the OECD Principles issued in 1999 were a reaction to the Asian financial crisis in 1997 and 1998. The accounting fraud in major companies like Enron and Worldcom, the access to privileged information and the episodes of tax evasion, have increased the debate on this issue. The aforementioned cases have raised serious questions about the adequacy of the existing solutions to a wide range of problems, such as strengthening the credibility of financial information and the efficiency of the supervisory systems of listed companies.

In this regard, with the aim of providing mechanisms to protect investors' rights and interests, as well as enabling markets to control managerial actions, national and supranational entities with legislative and regulatory powers have been publishing "Codes of Best Practices for Corporate Governance”. Seeking to transpose corporate governance to the domestic context, in 1999 the Portuguese Securities Market Commission (CMVM) approved a set of Recommendations on Corporate Governance. Since then, the CMVM recommendations on corporate governance have been constantly evolving with regard to their content and regulatory environment. With the recent publication of Regulation No 4/2013 of 18 July of 2013, there are now more than fifty CMVM recommendations with a direct impact on the corporate governance of companies in general, and on the governance of listed companies in particular.

In Portugal, companies issuing shares to trade on a regulated market are legally required to provide information on whether they comply with the recommendations contained in the Corporate Governance Code and to explain when they do not. The "comply or explain" approach, with origins in the United Kingdom, has been adopted by most European countries, as it was considered that listed companies should be required to include a coherent and descriptive statement in their annual reports identifying the fundamental pillars of their corporate governance structures and practices.

Considering the relevance and timeliness of corporate governance, this study aims to analyse the determinants of the level of corporate governance disclosure (CGD) by Portuguese companies listed on Euronext Lisbon between 2005 and 2011, a market characterized by a strong concentration of ownership and a civil law legal system which provides weak legal protection for investors. The motivation for this study stems from: (a) the importance of corporate governance disclosure for well-functioning capital markets and better investor protection; (b) the reduced amount of theoretical and empirical research in Portugal about the governance of companies.

To answer the question "what are the determinants of the level of corporate governance disclosure?" we divided the hypotheses into three groups: ownership structure, company management and supervisory structures and other 
specific company characteristics. We expect to contribute to the understanding of this problem, aiming to provide evidence on the determinants of the level of corporate governance disclosure.

The information used to assess companies' corporate governance practices was acquired both from annual reports and corporate governance reports, since these are the main documents published by companies to disseminate information to corporate stakeholders and because the release of an annual corporate governance report is mandatory for all companies listed on Euronext Lisbon.

The remainder of the paper is organized as follows. The next section discusses the relevant prior literature. Section 2 develops the research hypotheses. Section 3 outlines the sample, the research methodology and defines the variables used in the empirical analysis, while section 4 presents and discusses the main results. Finally, section 5 concludes the paper.

\section{Literature review}

Verrecchia (2001) argues that there is no comprehensive theory that explains the disclosure of information phenomena. Dye (2001) disagrees in part with what is stated by Verrecchia (2001) and considers that there is a theory about voluntary disclosure framed by Game Theory, under the premise that a company will disclose favourable information and hide unfavourable information.

Verrecchia (2001) suggests three categories of disclosure research in accounting: associationbased disclosure, discretionary-based disclosure and efficiency-based disclosure. In the first category, the main study objective is to analyse the effects of disclosure on changes or disruptions in investor behaviour. In the second category, in which this study is framed, the main objective is to explain how managers and/or companies exercise discretion with regard to the disclosure of information about which they have an understanding. In the third category, studies on efficiency-based disclosure investigate which information is unconditionally preferred and most efficient in the absence of prior knowledge of the information.

Research on voluntary disclosure relies on information asymmetry theory and complements the positive theory of accounting in the attention given to capital market motivations for accounting and disclosure decisions (Healy and Palepu, 2001). These studies assume that managers have more information on the expected results than outside investors and suggest that, depending on how the accounting and auditing regulations works, managers will seek an equilibrium between accounting options and disclosures, namely between disclosing more information to the market or managing the disclosure for contractual, political or corporate governance reasons.

Within the corporate governance framework, the OECD and regulators in many countries consider corporate governance structures and the disclosure of information as important ways to protect institutional investors and to improve the efficiency of capital markets (OECD, 1999). Given that the disclosure of information is selective and all forms of management manipulation cannot be avoided, an appropriate corporate governance structure may force managers to increase the level of disclosure.

Deciding whether corporate governance disclosure should be voluntary or mandatory is a central concern to regulators. The "comply or explain" model is the most common one used worldwide (Europe, Australia, New Zealand, Singapore, Hong Kong and many other countries). That means that companies are not required to comply with every rule in the Corporate Governance Code, but must justify non-compliance situations. As a result, the individuals or entities to which information is addressed will use it to make their decisions. Also, rules compliance will influence share price and the capital market reputation of companies.

However, governance practices differ significantly across countries (Doidge, Karolyi $\&$ Stultz, 2007). Although each country issues recommendations on corporate governance 
addressed to all listed companies, the level of compliance varies significantly across companies (Gompers, Ishii \& Metrick, 2003). This variation suggests that compliance with corporate governance codes is, in part, a discretionary choice. In fact, governance codes in many European countries such as Portugal are voluntary and non-binding (OECD, 2009).

In this case, the disclosure of information on governance practices is a good indicator of the quality of the corporate governance structure (Lokman, Mula \& Cotter, 2014). According to Berglof and Pajuste (2005), the disclosure of corporate governance practices increases corporate transparency and reduces the incidence of fraud. Donnelly and Mulcahy (2008) point out that the existence of appropriate corporate governance structures minimizes the risk of managerial expropriation generated by information asymmetry.

The definition of corporate governance has been associated with the "principal-agent" or "agency" problem, which occurs when there are conflicts of interests between shareholders, managers, creditors and employees of a company, caused by the separation of ownership and control. The voluntary disclosure of information plays an important role in the management of relations between the various stakeholders in a company. In Portugal, the existence of an overwhelming majority of small and medium-sized companies and a strong ownership concentration has led to changes in the way of analysing agency relations. If, on the one hand, in companies where agent and principal roles overlap, the moral hazard is higher, since there is no moderator of the principal's actions (Chung, 1993), on the other hand, the supervising of management is more efficient and enables incentives to be more aligned, since the managers and controlling shareholders are often the same people, with only one prevailing aspiration, which is to create value for the company in the medium and long term (Abreu, 2013). A high level of ownership concentration among a small number of shareholders is also boosted by weak protection of minority shareholders, which enables a controlling shareholder to extract private benefits more easily.

Agency theory has been applied to the study of corporate governance disclosure (Lokman et al., 2014, Mallin and Ow-Yong, 2012, Turrent and Rodríguez-Ariza, 2012). The results found suggest that the presence of solid corporate governance structures contributes to increasing disclosure transparency.

Stakeholder theory argues that there are other groups - creditors, employees, customers, suppliers, society, government and interest groups - which are also the responsibility of companies, in addition to shareholders. Its application to the Portuguese context presumes some ineffectiveness, given the high concentration of ownership, since the tendency will be to privilege large shareholders, ignoring minority shareholders' interests.

In fact, the challenging framework posed by agency theory and asymmetric information was pivotal when choosing this area of study.

The next section introduces the research hypotheses.

\section{Development of the hypotheses}

\section{I The relationship between ownership structure and disclosure}

\section{I.I Ownership concentration}

According to agency theory, it is reasonable to assume that the higher the ownership concentration, the lower the separation of ownership and management and the lower the information asymmetry. For example, Fan and Wong (2002) studied the relationship between the ownership structure and earnings informativeness of 977 companies listed in East Asian markets and found that concentrated ownership and the related pyramidal and cross-holding structures create agency conflicts between controlling owners and outside investors. In fact, the latter consider that the information disclosed has no credibility and only serves the interests of the former. 
When minority shareholders are in the minority their sphere of influence in companies tends to contract, therefore slowing down the disclosure of information to the market.

The level of influence of shareholders in a minority position over a company may decrease; therefore companies tend to disclose less information. Thus, from the perspective of stakeholder theory, the concentration of ownership has a strong influence on the level of information dissemination (Tsamenyi, EnninfulAdu \& Onumah, 2007; Ntim, Opong, Danbolt $\&$ Thomas, 2012).

Several studies, conducted in different countries, find a negative relationship between the concentration of ownership and disclosure (Arcay and Vázquez, 2005; Oliveira, Rodrigues \& Craig, 2006; Barako, Hancock \& Izan, 2006; Silveira and Barros, 2008; Ntim et al., 2012; Turrent and Rodríguez-Ariza, 2012; Allegrini and Greco, 2013; Costa, Oliveira, Rodrigues \& Craig, 2013; Hunziker, 2014). Therefore, we formulated the following hypothesis:

$\boldsymbol{H}_{1 a}:$ there is a negative relationship between ownership concentration and the level of CGD.

\section{I.2 Board of director ownership}

Disclosure decisions are the result of the willingness of managers to reduce the supervisory costs that shareholders would have to bear to avoid agency problems. In fact, managers with a larger share of capital have less incentive to expropriate shareholders and therefore make fewer decisions to maximize their personal utility (Barros et al., 2013).

Li and Qi (2008) observe that the higher the participation of managers in the capital, the greater the level of information disclosure. This participation, as well as contributing to increasing concerns about the potential economic consequences of their decisions, reduces agency costs and increases the level of disclosure. In Portugal, where ownership is highly concentrated and the systems for protecting minority shareholders are less efficient, managerial ownership can potentially bring managers and shareholders closer by increasing the level of disclosure.

Empirically, some studies confirm a positive relationship between managerial ownership and disclosure (Kateb, 2012; Barros, Boubaker \& Hamrouni, 2013, Hunziker, 2014). In this context, the following hypothesis is formulated:

\section{$\boldsymbol{H}_{16}$ : there is a positive relationship between board of director ownership and the level of $C G D$.}

\section{I.3 Foreign investor ownership}

In general, foreign investors have more difficulty in controlling corporate managers, not only because of territorial differences, but also due to cultural and linguistic barriers (Xiao and Yuan, 2007), and they are subject to a higher level of information asymmetry and higher risk of misjudgement. The high cost of gathering information about companies is more likely to discourage foreign investments, if investors take their investment decisions based on the trade-off between expected gains and costs (Mangena and Tauringana, 2007). In these cases, companies with foreign investors have a tendency to disclose more information to avoid the devaluation of their shares. Consistent with this, Mangena and Tauringana (2007) found that foreign investors have a preference for companies that engage in greater disclosure.

Empirically, Haniffa and Cooke (2002) found a positive relationship between foreign investor ownership and the level of disclosure. Similar results are supported by Lakhal (2006), Barako et al. (2006), Wang, Sewon and Claiborne (2008) and Alhazaimeh, Palaniappan and Almsafir (2014). This relationship corroborates the argument that companies need to disclose more information if they want to access international funds. In this context, the following hypothesis is formulated: 
$\boldsymbol{H}_{1 i}:$ there is a positive relationship between foreign investor ownership and the level of $C G D$.

\subsection{The relationship between company management and supervisory structures and disclosure}

\subsection{Board size}

From an agency theory perspective, board size is an important corporate governance mechanism for monitoring and advising management (Fama and Jensen, 1983, Allegrini and Greco, 2013). If, on the one hand, as Coles, Daniel and Naveen (2008) reported, large companies tend to have larger boards due to the complexity of their activities, on the other hand, the existence of larger boards can make communication, coordination and interaction between managers difficult, leading to a slower decision-making process (Yermack, 1996), adversely contributing to a lack of managerial responsibility (Jensen, 1993). However, Cormier, Ledoux and Magnan (2011) found a negative correlation between the quadratic term of board size and social and environmental disclosures in a sample of large Canadian companies.

A review of the literature shows that there is a strong relationship between the level of disclosure and board size. Lemos, Rodrigues and Ariza (2009) find empirical evidence to suggest a relationship between board size and the level of derivative instrument disclosure by Portuguese listed companies. In this context, the following hypothesis is formulated:

$\boldsymbol{H}_{2 a}:$ there is a positive relationship between board size and the level of CGD.

\subsubsection{Board Independence}

Fama and Jensen (1983) argue that the effectiveness of the board as a mechanism for corporate control depends on the number of executive and non-executive members that comprise it. On the other hand, there is a stream of research that is sceptical about the effectiveness of non-executive directors - partly stemming from their possible loyalty to managers who appoint them to the board or because the culture of the board of directors avoids conflicts (Jensen, 1993). The effectiveness of non-executive directors can also be influenced by legislation and reputation costs. Haniffa and Cooke (2002) suggest that the presence of non-executive directors on a board improves accountability and board transparency. Based on a meta-analysis study, García-Meca and Sánchez-Ballesta (2010) found that board independence offers a high level of protection to shareholders.

Nevertheless, there is a generalized consensus that the likelihood of accounting frauds and earnings management is smaller for companies whose boards include a large number of independent directors. In addition, the idea has been put forward that independent boards disclose more information (Leung and Horwitz, 2004). The analysis of board of director independence is framed by agency theory and complemented by stakeholder theory. The important role of independent directors on the board, evidenced by the literature, has led most corporate governance codes to recommend their presence on boards.

Soheilyfar, Tamimi, Ahmadi and Takhtaei (2014) found a significant and positive relationship between the quality of disclosure and board independence. The studies of Lanzana (2004), Arcay and Vázquez (2005), Cheng and Courteney (2006), Cerbionni and Parbonnetti (2007), Mallin and Ow-Yong (2012), Samaha, Dahawy, Hussainey and Stapledon (2012), Barros et al. (2013) and Oliveira, Rodrigues and Craig (2013) show similar results. On the other hand, Eng and Mak (2003), Gul and Leung (2004) and Rouf (2011) observed a negative relationship between the two variables. Therefore, the following hypothesis is formulated:

\section{$\boldsymbol{H}_{2 b}$ : there is a positive relationship between board independence and the level of CGD.}

\subsubsection{Unitary leadership structures}

In recent years, international governance regulators have promoted the separation of 
the chairman and CEO positions, through recommendations directed towards listed companies. The arguments for separating the roles of chairman and CEO are persuasive because separation gives boards a structural basis for overseeing a company's management and limits potential asymmetries of information.

Fama and Jensen (1983) argue that agency problems can be reduced through decision-making process separation between decision management and decision control. Forker (1992) suggests that combined leadership can attribute higher opportunity losses to the disclosure of information on share option benefits. Wong (2001) does not find any relationship between unitary leadership structures (combined leadership) and the level of disclosure of information. Haniffa and Cooke (2002), Cheng and Courtney (2006) and Kelton and Yang (2008) confirm this result.

Gul and Leung (2004) and Cerbioni and Parbonetti (2007) observe, as expected, that companies with combined leadership have a lower level of corporate disclosures. More recently, Rouf (2011), Samaha et al. (2012), Allegrini and Greco (2013) and Scholtz and Smit (2015) have observed a similar relationship. In the Portuguese context, Rodrigues et al. (2017) found a negative relationship. Therefore, we formulated the following research hypothesis:

$\boldsymbol{H}_{2 c}:$ there is a negative relationship between a unitary leadership structure and the level of CGD.

\subsubsection{Share-based director incentive schemes}

The use of stock option plans is an important feature of executive compensation as well as a mechanism to control agency conflicts. Nagar, Nanda and Wisocki (2003) suggest that stock price-based incentives draw out both bad news and good news disclosures from managers. Verrechia (1983) argues that companies release good news when stock prices rise. On the other hand, the retention of information leads to possible litigation costs and a decrease in the share price due to investors realising that this retention of information is a sign of "bad news". Managers have incentives to disseminate corporate governance information because it boosts the market's perception of company quality.

In this respect, Nagar et al. (2003), Arcay and Vázquez (2005) and Lakhal (2006) report a positive relationship between the existence of manager stock option plans and the level of corporate disclosure. Therefore, the following hypothesis is formulated:

\section{$\boldsymbol{H}_{2 d} \cdot$ there is a positive relationship between share-based director incentive schemes and the level of CGD.}

\subsubsection{External audit quality}

According to agency and stakeholder theories, large audit firms can influence the level and quality of CGD (Barako et al., 2006). Large audit firms may be seen as an important mechanism for increasing confidence in the financial information and performance of a company's management (Haniffa and Hudaib, 2007). For instance, Barako et al. (2006) state that large audit firms provide higher quality audits compared to small audit firms. Jensen and Meckling (1976), Watts and Zimmerman (1986) and Haniffa and Cooke (2002) argue that large audit firms can be a mechanism for limiting agents' opportunistic behaviour. Therefore, the quality of the audit function can improve the level of corporate governance disclosure (Eng and Mak, 2003).

However, the empirical evidence is inconsistent. Hannifa and Cooke (2002), Eng and Mak (2003) and Gul and Leung (2004) found no significant relationship between the size of the audit firm and the disclosure of information. On the other hand, Oliveira et al. (2006), Lopes and Rodrigues (2007), Wang et al. (2008), Ntim et al. (2012), Al-Janadi, Rahman and Omar (2013), Barros et al. (2013), Costa et al. (2013), Jouirou and Chenguel (2014) and Al-Bassam, Ntim, 
Opong and Downs (2015) show a significant positive relationship. Therefore, the following hypothesis is formulated:

$\boldsymbol{H}_{2 e}:$ there is a positive relationship between companies being audited by Big 4 accounting firms and the level of CGD.

\subsection{The relationship between company characteristics and disclosure}

\subsection{Degree of internationalization}

El-Gazzar, Finn and Jacob (1999) report that companies with a higher degree of internationalization have greater visibility in international markets. Lopes and Rodrigues (2007) argue that these companies signal their quality to different stakeholders by increasing the level of information disclosed. The same authors point out that even unlisted multinationals seek to increase the information disclosed in their annual reports. Also, we must note that multinationals have to comply with the information requirements of both the country of origin and the countries where they are present.

The results of Macagnan (2009) suggest that the level of internationalization explains the greater extent of information disclosure for intangible resources. In this context, Oliveira et al. (2006) and Lopes and Rodrigues (2007) do not find any significant influence of the degree of internationalization on disclosure. Therefore, the following hypothesis is formulated:

$\boldsymbol{H}_{3 \boldsymbol{a}}:$ there is a positive relationship between the degree of internationalization of companies and the level of CGD.

\subsubsection{Leverage}

According to Jensen and Meckling (1976), raising the level of indebtedness, either to reduce agency costs by opening capital to external investors or for some other reason, could lead a company to face the so-called agency cost of debt, generated by the conflict of interests between shareholders and creditors. Agency costs of debt occur when owners feel motivated to invest in high-risk activities, giving origin to costs of contractual guarantees for creditor protection and/ or the likelihood of failure produced by high debt levels. In this situation, managers are encouraged to make wealth transfers to the detriment of creditors. To prevent this, creditors require more information to be disclosed, thereby reducing information asymmetry, predicting future cash flows and assessing the company's ability to pay its debts. In Portugal, the main company creditors, banks, do not encourage companies with higher debt levels to disclose information in annual reports, since they use informal mechanisms to obtain such information (Oliveira et al., 2013).

In general, the results of empirical studies that relate leverage and information disclosure indicate conflicting signs. Some authors find a positive relationship (Kateb, 2012; Hunziker, 2014; Jouirou and Chenguel, 2014), while others do not observe any relationship (Hannifa and Cooke, 2002; Oliveira et al., 2006; Lopes and Rodrigues, 2007; Allegrini and Greco, 2013; Ghasempour and Mdyusof, 2014) and some even show a negative relationship (Eng and Mak, 2003; Barros et al., 2013; Oliveira et al., 2013). Therefore, the following hypothesis is formulated:

$\boldsymbol{H}_{3 b}$ : there is a relationship between leverage and the level of CGD.

\section{Research methodology and sample definition}

\section{I Sample and information gathering}

Our study's population consists of all non-financial Portuguese companies listed on Euronext Lisbon, from 2005 to 2011. We eliminated all firms operating in the financial sector from the panel due to their working capital structure and because they are subject to additional mechanisms of corporate governance imposed by the regulator, and all the anonymous sports societies because their accounting is distinct from that of companies. Our final sample 
comprises a total of 263 observations, as described in the table in Appendix I.

\subsection{Empirical model}

To evaluate the attributes that explain the level of CGD, we used an ordinal logistic regression model that provides a useful approach when the dependent variable is categorical.

Hair, Anderson, Tatham and Black (1998) suggest several reasons for choosing logistic regression for research: (1) it is not necessary to assume normal data distribution; (2) it is a generic and robust technique, with a wide spectrum of application; (3) it is a similar technique to multiple linear regression; and (4) the probability of occurrence of an event can be estimated directly. Ordinal logistic regression differs from multiple linear regression because its dependent variable is categorical rather than quantitative. The regression methods also differ because an ordinal logistic regression's outcome is expressed as a probability of occurrence, while in a simple regression we obtain some numerical value (Marôco, 2007).

We use the following ordinal logistic regression model:

$\mathrm{CGD} \mathrm{C}_{i}=\beta_{0}+\beta_{1} \mathrm{CONC}$ $\mathrm{Q}_{i}+\beta_{2} \mathrm{~F}$ I OWN ${ }_{i}+\beta_{3} \mathrm{BOWN}_{i}+\mathrm{b}_{4} \mathrm{Log}_{-}$ $\mathrm{BSIZE}_{i}+\mathrm{b}_{5} \mathrm{BIND}_{i}+\mathrm{b}_{6} \mathrm{CHAIRCEO}_{i}++\mathrm{b}_{7} \mathrm{SOC}_{i}+$ $\mathrm{b}_{8} \mathrm{BIG}_{i}+\mathrm{b}_{9} \mathrm{INT}_{i}+\beta_{10} \mathrm{LEV}_{i}+\varepsilon_{i}$

\section{Where:}

CGD - percentage of items disclosed by the companies out of the total relevant items, that is, the total items that make up the disclosure index minus the number of responses classified as "not applicable" (Haniffa and Cooke 2002; Samaha et al. 2012);

CONC_ $Q_{i}$ - percentage of shares held by shareholders with at least $2 \%$ of the total number of shares issued.

FIOWN $\mathrm{N}_{\mathrm{i}}$ - percentage of shares held by foreign investors (banks, insurance companies, pension funds and foreign investment funds) whose ownership $\geq 2 \%$ of the total number of shares issued;

BOWN - percentage of shares held by directors (Ghazali and Weetman, 2006);
Log_BSIZE - logarithm of the number of board members (Yermack, 1996; Silveira, 2004; Nekhili, Hussainey, Cheffi, Chtioui \& Tchakoute-Tchuigoua, 2016);

BIND $_{\mathrm{i}}$ - percentage of independent directors on the board;

$\mathrm{CHAIRCEO}_{\mathrm{I}}-$ dummy: 1 if the leadership structure is unitary, and 0 otherwise;

$\mathrm{SOC}_{i}-$ dummy: 1 if the companies operate share-based incentive schemes, and 0 otherwise;

BIG4-dummy: 1 if the firm's accounts are certified by a Big4 accounting firm (PricewaterhouseCoopers, Deloitte, Ernst \& Young and KPMG), and 0 otherwise;

INT $_{\mathrm{i}}$-degree of internationalization: value of foreign sales divided by total assets at the end of the year;

$\mathrm{LEV}_{\mathrm{i}}$ - leverage: proxied by the ratio of total remunerated debt divided by total assets at the end of the year;

$\mathrm{YEAR}_{\mathrm{i}}$ - six dummy variables for each of the years under analysis;

$\varepsilon_{i}-$ Model errors.

\subsection{Variables definition}

\subsection{Dependent variable - disclosure index}

To analyse the level of corporate governance disclosure by Portuguese companies and its determinants, a specific disclosure index was constructed for this research, similar to other studies (Yuen, Liu, Zhang \& Lu, 2009, Mallin and Ow-Young, 2012; Samaha et al., 2012; Turrent and Rodriguez-Ariza, 2012; Lokman et al., 2014). Our data sources include consolidated annual reports and corporate governance reports (for the years from 2005 to 2011), obtained from the website of the CMVM.

The primary research instrument used was a pilot test, based on a research protocol developed in the context of corporate governance by recognized institutions and organizations (World Bank, United Nations Conference on Trade and Development - UNCTAD and Standard \& Poor's), as well as on the OCDE Principles of corporate governance and Portuguese recommendations regarding corporate governance.

The final disclosure index (CGD) includes a total of 82 corporate governance attributes grouped into six categories of information: 
management structure; specialized committees (remuneration and appointment); audit and risk management; ownership structure; compliance and corporate responsibility; and financial transparency. The list of items included in the disclosure index is developed in Appendix 2.

In order to conduct an accurate and reliable content analysis, we identified the meaning of each attribute included in the disclosure index and assessed every attribute twice. Additionally, objective criteria were defined for coding the attributes. All attributes, disclosed or not and applicable or not, were recorded for each firm in each financial year.

For each company, we analysed both annual and corporate governance reports and verified if there was any reference to any of the attributes analysed in this study. If there was at least one reference to an attribute, the value 1 was assigned to the firm for the specific year of the observation. When no reference to the attribute was observed, the attribute takes the value 0 . If the question does not apply to the company, the attribute was classified as "not applicable" (Haniffa and Cooke, 2002; Ghazali and Weetman, 2006; Lim et al., 2007; Samaha et al., 2012). Given that binary indicators are used to measure the attributes, even if an attribute appeared twice or more in the same report, it was only measured once.

The total disclosure score for each company in each year is obtained by the following formula:

$$
\mathbf{D}=\sum_{i=1}^{n} \frac{I_{i}}{R} \times 100
$$

Where: DI is the disclosure index, $\mathrm{n}$ measures the total number of attributes, $I_{i}$ is an indicator taking the value 1 if the attribute is disclosed and 0 otherwise and $\mathrm{R}$ is the number of all reported attributes, excluding the nonapplicable attributes. So, $0 \leq \mathrm{DI} \leq 100$.
This study uses an unweighted disclosure index, that is, a scoring system which assumes all the information items have the same level of importance for the various users of the information.

\subsubsection{Independent variables}

The selection of the independent variables was based on the research hypotheses proposed. We take the natural logarithm of the board size to solve possible problems of correlation between the independent variables. The relevant data was obtained from the companies' consolidated annual reports and corporate governance reports. In the absence or impossibility of obtaining the required information, the data was considered not disclosed and statistically treated as missing.

\section{$4 \cdot 3 \cdot 3$ Control variables}

Based on the existing literature, we also introduced control variables to observe determinants of the level of CGD and to facilitate the isolation of the link leading from the independent to the dependent variables (Samaha et al., 2012; Turrent and Rodríguez-Ariza, 2012, and Barros et al., 2013). Controls for type of industry, number of years since the company was accepted into the official securities market and PSI-20 index, return on equity (ROE) as well as year dummies for controlling time (YEAR2:2006; YEAR3: 2007; YEAR4: 2008; YEAR5: 2009; YEAR6: 2010; YEAR7: 2011) are included.

\section{Empirical results}

\section{I Descriptive Statistics}

The descriptive statistics for the continuous variables are shown in Panels A, B and C of Table 1. 
Table 1.

Descriptive statistics

Panel A: Dependent Variable

\begin{tabular}{lccccccc}
\hline CGD & $\mathbf{2 0 0 5}$ & $\mathbf{2 0 0 6}$ & $\mathbf{2 0 0 7}$ & $\mathbf{2 0 0 8}$ & $\mathbf{2 0 0 9}$ & $\mathbf{2 0 1 0}$ & $\mathbf{2 0 1 1}$ \\
\hline Mean & $51.3 \%$ & $54.7 \%$ & $59.7 \%$ & $68.1 \%$ & $71.9 \%$ & $76.3 \%$ & $77.7 \%$ \\
Median & $53.8 \%$ & $54.5 \%$ & $59.1 \%$ & $65.9 \%$ & $75.3 \%$ & $77.0 \%$ & $78.5 \%$ \\
Std. Deviation & $13.5 \%$ & $13.8 \%$ & $13.7 \%$ & $12.9 \%$ & $12.9 \%$ & $11.3 \%$ & $11.0 \%$ \\
Minimum & $26.8 \%$ & $27.7 \%$ & $27.3 \%$ & $36.1 \%$ & $41.9 \%$ & $48.3 \%$ & $51.5 \%$ \\
Maximum & $75.9 \%$ & $76.3 \%$ & $84.6 \%$ & $86.8 \%$ & $89.6 \%$ & $91.1 \%$ & $93.4 \%$ \\
$\mathrm{~N}$ & 34 & 35 & 37 & 40 & 39 & 39 & 39 \\
\hline
\end{tabular}

Panel B: Continuous independent variables

\begin{tabular}{|c|c|c|c|c|c|c|c|c|c|}
\hline & YEAR & $\mathbf{N}$ & CONC_Q & FIOWN & BOWN & BSIZE & BIND & INT & LEV \\
\hline & 2005 & 34 & 0.718 & 0.112 & 0.239 & 7.88 & 0.35 & 0.322 & 0.738 \\
\hline & 2006 & 35 & 0.708 & 0.124 & 0.239 & 8.17 & 0.40 & 0.353 & 0.726 \\
\hline & 2007 & 37 & 0.716 & 0.116 & 0.241 & 8.19 & 0.39 & 0.334 & 0.727 \\
\hline \multirow[t]{6}{*}{ Mean } & 2008 & 40 & 0.760 & 0.108 & 0.236 & 8.83 & 0.43 & 0.338 & 0.753 \\
\hline & 2009 & 39 & 0.758 & 0.097 & 0.276 & 9.18 & 0.47 & 0.332 & 0.748 \\
\hline & 2010 & 39 & 0.773 & 0.100 & 0.270 & 9.39 & 0.51 & 0.346 & 0.727 \\
\hline & 2011 & 39 & 0.776 & 0.109 & 0.265 & 9.39 & 0.51 & 0.364 & 0.749 \\
\hline & Mean & 263 & 0.75 & 0.11 & 0.25 & 8.76 & 0.44 & 0.34 & 0.74 \\
\hline & Median & 263 & 0.77 & 0.07 & 0.10 & 8 & 0.50 & 0.26 & 0.72 \\
\hline Sample & Std. Deviation & 263 & 0.15 & 0.12 & 0.28 & 4.10 & 0.24 & 0.32 & 0.20 \\
\hline \multirow[t]{2}{*}{ Total } & Minimum & 263 & 0.22 & 0.00 & 0.00 & 3 & 0.00 & 0.00 & 0.40 \\
\hline & Maximum & 263 & 1.00 & 0.60 & 0.89 & 25 & 0.81 & 0.99 & 1.91 \\
\hline
\end{tabular}

Panel C: Dummy independent variables

\begin{tabular}{lcccccccc}
\hline & $\mathbf{2 0 0 5}$ & $\mathbf{2 0 0 6}$ & $\mathbf{2 0 0 7}$ & $\mathbf{2 0 0 8}$ & $\mathbf{2 0 0 9}$ & $\mathbf{2 0 1 0}$ & $\mathbf{2 0 1 1}$ & Mean \\
\hline CHAIRCEO $_{\mathrm{i}}$ & $61.8 \%$ & $60.0 \%$ & $59.5 \%$ & $50.0 \%$ & $48.7 \%$ & $51.3 \%$ & $48.7 \%$ & $54.00 \%$ \\
SOC & $14.7 \%$ & $14.3 \%$ & $13.5 \%$ & $12.5 \%$ & $12.8 \%$ & $17.9 \%$ & $12.8 \%$ & $14.05 \%$ \\
BIG4 & $20.6 \%$ & $25.7 \%$ & $32.4 \%$ & $32.5 \%$ & $33.3 \%$ & $33.3 \%$ & $33.3 \%$ & $30.41 \%$ \\
\hline
\end{tabular}

As shown in Panel A of table 1, the CGD index ranged from $26.8 \%$ to $75.9 \%$, with a mean of $51.3 \%$ and a standard deviation of $13.5 \%$ in 2005. The mean value of the CGD index increased over the period analysed, reaching an average of $77.7 \%$ in 2011 . The results indicate that there is a wide range of CGD practices used by Portuguese companies.

According to Panel $\mathrm{B}$, the average debt levels of the Portuguese companies were equal to almost $42.7 \%$ of their assets over the period under analysis. The mean (1.20) and median 
(1.09) ratios for Tobin's $Q$, a proxy for growth opportunities, was positive, indicating that the Portuguese companies are growing. The distribution of total asset value was normalised, using a log transformation, and its mean level equals 8.83. Finally, the average return on equity ratio, a proxy for performance, was equal to 12.7\% between 2005 and 2011.

Panel B shows that the mean percentage of shares held by shareholders with at least 2\% of share capital reached $74.60 \%$, suggesting that the ownership structure is highly concentrated in these companies. Moreover, the average for the CONC_Q variable increased from $71.8 \%$ in 2005 to $77.6 \%$ in 2011 . On average, the percentage of shares held by foreign investors is $10.90 \%$, although the highest percentage of shares owned by them in one sample company reached $60 \%$. The percentage of equity owned by directors ranges from a minimum of zero to a maximum of $89 \%$, with a median value of $25.30 \%$.

The number board members ranges from 3 to 25, with a mean of 9 directors, which according to Yermack (1996) is a number close to that recommended by studies that relate the market value of companies with the number of board members. On average, the percentage of independent non-executive directors on the board was nearly $44 \%$, showing a considerable increase over the sample period from 35\% in 2005 to $51 \%$ in 2011 . The degree of internationalization of the companies ranges considerably, from $0 \%$ to $99.2 \%$, with a median value of $34.15 \%$. The average level of debt for this sample is $73.86 \%$. The high debt level indicates that there may not be scope for further debt to be raised by the companies in the sample.

As shown in Panel C, the mean percentage of companies that have unitary leadership structures is $54 \%$. The results show that $14 \%$ of the sample companies operate share-based incentive schemes. Finally, the percentage of companies audited by a Big 4 accounting firm grew by $28 \%$ between 2005 and 2011, suggesting that the sample companies prefer to be certified by a large audit firm.

\section{$5 \cdot 2$ Bivariate analysis}

The Kolmogorov-Smirnov statistical test shows that the dependent variable does not follow a normal distribution. To solve the normality problem, we transformed the continuous dependent variable (CGD) into a categorical measure and carried out an ordinal logistic regression. According to the percentile analysis conducted for the CGD categorical index, the relationship between the latent corporate governance disclosure $\left(y^{*}\right)$ and the observed index can be observed at the following cut-off points: $\mathrm{y}=1$ if $\mathrm{y}^{*} \leq 0.60 ; \mathrm{y}=2$ for $0.601<\mathrm{y}^{*} \leq 0.80$; $\mathrm{y}$ $=3$ for $\mathrm{y}^{*}>0.801$.

The bivariate relationships between the continuous variables are presented in table 2 . As the dependent variable follows a non-normal distribution, we proceed to an analysis of the Spearman's correlation coefficients.

Table 2 shows that the disclosure index is correlated with the variables that characterize the company's management structure. Overall, the coefficients of correlation show us that the problem of collinearity between the variables may not be of particular relevance in this study. To evaluate the association between the qualitative variables CHAIRCEO, SOC and BIG4, the Quisquare independence test was applied, which did not reject the hypothesis of independence between the variables.

No independent variable in our regression had a variance inflation factor exceeding 2.2, suggesting minimal multi-collinearity and stability of parameter estimates, for which reason it was possible to advance to the ordinal regression with confidence. 
Table 2.

Bivariate correlations (Spearman's correlation coefficients)

\begin{tabular}{|c|c|c|c|c|c|c|c|c|}
\hline & CGD & $\begin{array}{c}\text { Log } \\
\text { BSIZE }\end{array}$ & BIND & CONC_Q & FIOWN & BOWN & INT & LEV \\
\hline CGD & 1 & & & & & & & \\
\hline Log_BSIZE & $0.64^{* *}$ & 1 & & & & & & \\
\hline BIND & $0.63^{* *}$ & $0.57^{* *}$ & 1 & & & & & \\
\hline CONC_Q & $-0.17^{* *}$ & $-0.14^{*}$ & $-0.17^{* *}$ & 1 & & & & \\
\hline FIOWN & $0.20^{* *}$ & $0.19^{* *}$ & $0.19^{* *}$ & $-0.31^{* *}$ & 1 & & & \\
\hline BOWN & $-0.18^{* *}$ & $-0.32^{* *}$ & $-0.18^{* *}$ & -0.03 & -0.12 & 1 & & \\
\hline INT & 0.11 & 0.02 & 0.01 & -0.06 & 0.06 & $-0.12^{*}$ & 1 & \\
\hline LEV & $-0.22^{* *}$ & $-0.15^{*}$ & $-0.17^{* *}$ & $-0.13^{*}$ & 0.07 & $-0.17^{* *}$ & -0.03 & 1 \\
\hline
\end{tabular}

* Correlation is significant at the 0.05 level (2-tailed). ** Correlation is significant at the 0.01 level (2-tailed). N=263

\section{$5 \cdot 3$ Multivariate Analysis}

Like Franck and Sundgren (2012) and Costa et al. (2013), we fit an ordinal logistic regression model to pooled data, controlling for time effects. We also test the significance of each variable's relationship with CGD and eliminate

Table 3

\section{Results of the Ordinal Logistic Regression}

\begin{tabular}{|c|c|c|c|}
\hline & Expected sign & & \\
\hline & & Estimates & Sig. \\
\hline CONC_Q & - & $-3.162\left(^{*}\right)$ & $(0.024)$ \\
\hline FIOWN & + & $4.644\left(^{*}\right)$ & $(0.010)$ \\
\hline Log_BSIZE & + & $8.723(* *)$ & $(0.000)$ \\
\hline BIND & + & $\left.2.29{ }^{(* *}\right)$ & $(0.001)$ \\
\hline CHAIRCEO & - & $-1.315(*)$ & $(0.003)$ \\
\hline BIG4 & + & $1.346\left(^{*}\right)$ & $(0.003)$ \\
\hline INT & + & $2.232(*)$ & $(0.002)$ \\
\hline LEV & $+1-$ & $-7.075(* *)$ & $(0.000)$ \\
\hline YEAR3 & + & $2.359\left(^{*}\right)$ & \\
\hline YEAR4 & + & $\left.5.020{ }^{* *}\right)$ & \\
\hline YEAR5 & + & $5.903\left({ }^{* *}\right)$ & \\
\hline YEAR6 & + & $7.553(* *)$ & \\
\hline YEAR7 & + & $7.592(* *)$ & \\
\hline PSI-20 & & $1.376\left(^{*}\right)$ & \\
\hline $\mathrm{ICB} 2$ & & $-1.948(*)$ & \\
\hline 2Log Likelihood & & -202.575 & \\
\hline$\chi^{2}$ & & 358.532 & \\
\hline$\chi^{2}(\mathrm{p}$-value $)$ & & $<0.001$ & \\
\hline Nagelkerke Pseudo $\mathrm{R}^{2}$ & & 0.844 & \\
\hline Overall prediction occur. & & $66.7 \%$ & \\
\hline Observations & & 263 & \\
\hline
\end{tabular}

* Correlation is significant at the 0.05 level (2-tailed). ${ }^{* *}$ Correlation is significant at the 0.01 level (2-tailed). $\mathrm{N}=263$ outcome of interest. A summary of the results obtained from the data pool is shown in table 3. Nagelkerke's pseudo R-squared indicates that the independent variables explain $84.4 \%$ of the CGD index variation. 
As shown in table 3, share-based director incentive schemes does not influence the level of CGD and, likewise, board of director ownership does not seem to have any influence on the level of CGD. These results may be explained by the fact that these variables do not show substantial variations over the study time. The results in the sensitivity analysis corroborate the ones obtained in the previous scenario, thus not supporting hypothesis $\mathrm{H}_{1 \mathrm{~b}}$ and $\mathrm{H}_{2 \mathrm{~d}}$.

We find a negative effect of ownership concentration $(p<0.005)$ on the level of CGD, which supports hypothesis $\mathrm{H}_{1 \mathrm{a}}$, suggesting that companies with higher shareholder concentrations disclose, on average, less information on their governance structures. Again, this association suggests that the higher the ownership concentration, the greater the likelihood of managers making decisions regarding disclosure policy that maximize the large shareholders' wealth on behalf of minority shareholders. This problem is most evident in countries such as Portugal, where ownership is highly concentrated and the degree of protection for minority shareholders is poor.

The coefficient for the FIOWN variable is also positive and statistically significant $(\mathrm{p}<0.005)$. This therefore suggests that companies with foreign investors have greater incentives to report information in order to reduce potential political risks, inadequate legal protection and potential asymmetry of information. This is consistent with Haniffa and Cooke (2002) and Barako et al. (2006), thus supporting hypothesis $\mathrm{H}_{1 c}$

The sample's board size (Log_TAMC) coefficient is positive and highly significant $(\mathrm{p}<0001)$, meaning that corporate governance disclosure is higher for companies with larger boards, which supports our hypothesis $\mathrm{H}_{2 \mathrm{a}}$. A possible reason for this positive association can be explained by both agency and stakeholder theories, which suggest that a more diverse board boosts the level of corporate disclosure.

This result is consistent with Lemos et al. (2009), who analysed the disclosure for derivative instruments by Portuguese companies listed on Euronext Lisbon, between 2003 and 2009, and with the results of Al-Bassam et al. (2015). Furthermore, in line with the arguments of efficiency, flexibility, communication and coordination, suggested by Yermack (1996), we also tested if there is an optimal board size with five to nine directors, to be demonstrated by the presence of a negative quadratic coefficient $\left(\operatorname{BOARD}(\log )^{2}\right)$. However, the results do not provide evidence for this hypothesis.

The coefficient for BIND is positive and highly significant $(\mathrm{p}<0.001)$, thus supporting hypothesis $\mathrm{H}_{2 \mathrm{~b}}$. This result suggests that independent directors have greater incentives to motivate managers to disclose more voluntary information in annual reports. These results are in line with the studies carried out by Arcay and Vázquez (2005), Cheng and Courtenay (2006), Samaha et al. (2012), Oliveira et al. (2013) and Alhazaimeh et al. (2014), among others.

We found unitary leadership structures (CHAIRCEO) to be a good explanatory factor for corporate governance disclosure $(\mathrm{p}<0.005)$. This association suggests that, on average, companies with dual leadership disclose more information on corporate governance, which supports hypothesis $\mathrm{H}_{2 \mathrm{c}}$. This result suggests that unitary leadership structures weaken the supervisory function of the board, decreasing the level of information disclosed. Samaha et al. (2012) show similar results.

We find a positive and statistically significant $(\mathrm{p}<0.005)$ relationship for BIG4, meaning that the level of CGD is higher for companies audited by a Big 4 firm. This finding supports hypothesis $\mathrm{H}_{2 \mathrm{e}}$ and is consistent with the argument that companies audited by Big 4 accounting firms disclose, on average, more corporate governance information (Barako et al., 2006). Our results show that the sample companies audited by a Big 4 accounting firm exhibit high levels of CGD, ranging from $58.4 \%$ in 2005 to $78.6 \%$ in 2011 . This is consistent with the studies of Oliveira et al. (2006) and Lopes and 
Rodrigues (2007) conducted in the Portuguese context.

Regarding the degree of internationalization of companies, the coefficient of the INT variable is positive and statistically significant ( $\mathrm{p}<0.005$ ), thus supporting hypothesis $\mathrm{H}_{3 \mathrm{a}}$. This result suggests that more internationalized companies have greater incentives to disclose more information. In accordance with the findings of Webb, Chan and Sun (2008) and Macagnam (2009), this study shows a positive relationship between the degree of internationalization and the level of CGD.

The leverage coefficient (LEV) was found to be statistically significant $(\mathrm{p}<0.001)$ and negatively associated with the level of CGD. This association suggests that companies with a lower debt ratio disclose more information on corporate governance structures than companies with a higher debt ratio. Oliveira et al. (2013) also show a significant and positive association between leverage and disclosure, which further supports our hypothesis. For the authors, a possible reason for this negative association could be attributed to the nature of the relationship between banks and Portuguese companies, with banks having full access to information about companies, thus making the disclosure of additional information through reports and accounts less relevant.

Finally, the coefficient for the time control variables (YEAR3, YEAR4, YEAR5, YEAR6 and YEAR7) is positive and statistically significant, with the exception of 2006 (YEAR2). This seems reasonable because the level of CGD disclosure in 2006 is nearly equal to the one observed in 2005. The results substantiate the findings discussed on the aforementioned descriptive statistics, showing a more meaningful improvement in the level of CGD after 2007 (Table 1, Panel A). We also conclude that the level of CGD is higher for the companies that form part of the PSI 20 index and smaller for the companies from the basic materials sectors (ICB2).

\section{Conclusion}

Regardless of the fact that corporate governance is well-entrenched as a scientific construct and widely used in the international context, to our knowledge there are no studies that have analysed the relationship between the mechanisms of corporate governance and the level of CGD in annual reports, with reference to the Portuguese context. This paper contributes to the current literature by analysing the determinants of the level of corporate governance disclosure in a less studied country of Western Europe, characterized by a strong concentration of ownership and high debt rates. In terms of methodology, we use an ordinal logistic model to analyse the determinants of corporate governance disclosure, given the categorical nature of the dependent variable of the proposed model, which is also not usual in this type of study.

The results regarding the level of CGD show an increasing evolution between 2005 and 2011, suggesting that the revisions made to the Portuguese Corporate Governance Code in 2007 and 2010 had a positive influence on the level of disclosure. These results are of practical interest, particularly for the CMVM, because they reveal that regulatory efforts in this area contribute to an increase in disclosure.

The estimation of the model reveals, firstly, that companies with a high shareholder ownership concentration and unitary leadership structures disclose less information regarding their governance structures. On the other hand, it suggests that companies with a higher percentage of foreign investors, larger boards, a higher percentage of independent directors on the board, which are audited by a Big 4 accounting firm and which have higher levels of internationalization, disclose more information regarding their corporate governance structures.

To conclude, we find a significant relationship between corporate debt levels and the level of CGD, suggesting that, on average, less indebted companies disclose more information on 
their governance structures. Previous Portuguese studies on the disclosure of intellectual capital already point out the first and the last of the results found, which appears to be a feature of the country. Finally, the study's results show that two of the determinants defined a priori do not present statistical significance, these being board of director ownership and share-based director incentive schemes.

It can be concluded that the overall results strengthen the argument that corporate governance plays an important role within companies, helps to mitigate agency problems and ones arising from asymmetric information to answer the various stakeholder requests and, consequently, increases the level of CGD. To conclude, the results obtained in this study emphasize agency and stakeholder theories.

This study has theoretical and practical implications. Firstly, it contributes to the literature on disclosure, by focusing on information about corporate governance structure. Secondly, to the best of our knowledge, it adds the following determinants to the literature: foreign investor ownership, share-based director incentive schemes and degree of internationalization, which have been little explored so far.

Moreover, we applied a longitudinal analysis over a sampling period of seven years, a procedure little used in other studies of this nature. At the very least, the results obtained in this study can be useful for many regulatory purposes, such as formulating corporate governance recommendations and policies and even for investors and managers of companies, adding to their understanding of the reasons for disclosure.

There are intrinsic limitations to this study. First, it focuses on the information disclosed in annual reports and corporate governance reports, excluding other important sources of information such as analyst meetings, conference calls, interim reports, press releases, websites or others. Second, a non-weighted index is used, thus casting doubt on the external validity of the findings. Other limitations regard the researchers' subjective assessment to identify the items and to construct the disclosure index, thus creating potential errors related with the interpretation and classification of the information.

\section{References}

Abreu, M. E. C. (2013). Benefícios privados do controlo societário (Tese de Mestrado). Faculdade de Direito da Universidade Católica Portuguesa, Lisboa, Portugal.

Al-Bassam, W. M., Ntim, C. G., Opong, K. K., \& Downs, Y. (2015). Corporate boards and ownership structure as antecedents of corporate governance disclosure in Saudi Arabian publicly listed corporations. Business \& Society, 1-43.

Alhazaimeh, A., Palaniappan, R., \& Almsafir, M. (2014). The impact of corporate governance and ownership structure on voluntary disclosure in annual reports among listed Jordanian companies. Procedia-Social \& Behavioral Sciences, 129, 341348.

Al-Janadi, Y., Rahman, R. A., \& Omar, N. H. (2013). Corporate governance mechanisms and voluntary disclosure in Saudi Arabia. Research Journal of Finance \& Accounting, 4(4), 25-35.

Allegrini, M., \& Greco, G. (2013). Corporate boards, audit committees and voluntary disclosure: Evidence from Italian listed companies. Journal of Managementљ Governance, 17(1), 187-216.

Arcay, M. R. B., \& Vázquez, M. F. (2005). Corporate characteristics, governance rules and the extent of voluntary disclosure in Spain. Advances in Accounting, 21, 299-331.

Barako, D. G., Hancock, P., \& Izan, H. (2006). Factors influencing voluntary corporate disclosure by Kenyan companies. Corporate Governance: An International Review, 14(2), 107-125.

Barros, C. P., Boubaker, S., \& Hamrouni, A. (2013). Corporate governance and voluntary 
disclosure in France. The Journal of Applied Business Research, 29(2), 561-578.

Berglöf, E., \& Pajuste, A. (2005). What do firms disclose and why? Enforcing corporate governance and transparency in Central and Eastern Europe. Oxford Review of Economic Policy, 21(2), 178-197.

Berle, A. A., \& Means, G. C. (1932). The modern corporation and private property. NY: Macmillan.

Cerbioni, F., \& Parbonetti, A. (2007). Exploring the effects of corporate governance on intellectual capital disclosure: An analysis of European biotechnology companies. European Accounting Review, 16(4), 791-826.

Cheng, E. M., \& Courtenay, S. M. (2006). Board composition, regulatory regime and voluntary disclosure. The International Journal of Accounting, 41, 262-289.

Chung, K. H. (1993). Asset characteristics and corporate debt policy: An empirical test. Journal of Business Finance and Accounting, 20(1), 83-98.

Coles, J. L., Daniel, N. D., \& Naveen, L. (2008). Boards: Does one size fit all? Journal of Financial Economics, 87, 329-356.

Cormier, D., Ledoux, M. J., \& Magnan, M. (2011). The informational contribution of social and environmental disclosures for investors. Management Decision, 49(8), 1276-1304.

Costa, G. A., Oliveira, L., Rodrigues, L. L., \& Craig, R. (2013). Factors associated with the publication of a ceo letter. Corporate Communications: An International Journal, 18(4), 432-450.

Doidge, C., Karolyi, G. A., \& Stulz, R. M. (2007). Why do countries matter so much for corporate governance? Journal of Financial Economics, 86(1), 1-39.

Donnelly, R., \& Mulcahy, M. (2008). Board structure, ownership, and voluntary disclosure in Ireland. Corporate Governance: An International Review, 16(5), 416-429.
Dye, R. A. (2001). An evaluation of "essays on disclosure" and the disclosure literature in accounting. Journal of Accounting and Economics, $32,181-235$.

El-Gazzar, S. M., Finn, P. M., \& Jacob, R. (1999). An empirical investigation of multinational firms compliance with international accounting standards. The International Journal of Accounting, 34(2), 239-248.

Eng, L. L., \& Mak Y. T. (2003). Corporate governance and voluntary disclosure. Journal of Accounting \& Public Policy, 22(4), 325-345.

Fama, E. F., \& Jensen, M. C. (1983). Separation of ownership and control. Journal of Law and Economics, 46, 301-325.

Fan, J., \& Wong, T. (2002). Corporate ownership structure and the informativeness of accounting earnings in East Asia. Journal of Accounting \& Economics, 33, 401-425.

Forker, J. (1992). Corporate governance and disclosure quality. Accounting \& Business Research, 22(86), 111-124.

Franck, P., \& Sundgren, S. (2012). Determinants of internal governance quality: Evidence from Sweden. Managerial Auditing Journal, 27(7), 639-665.

Garcia-Meca, E., \& Sánchez-Ballesta, J. P. (2010). The association of board independence and ownership concentration with voluntary disclosure: A Meta-Analysis. European Accounting Review, 19(3), 603-627.

Ghasempour, A., \& MdYusof, M. A. (2014). The effect of fundamental determinants on voluntary disclosure of financial and nonfinancial information: The case of Tehran Stock Exchange. Journal of Accounting\& Marketing, 3(2), 1-6.

Ghazali, N., \& Weetman, P. (2006). Perpetuating traditional influences: Voluntary disclosure in Malaysia following the economic crisis. Journal of International Accounting Auditing \& Taxation, 15(2), 226-248. 
Gompers, P., Ishii, J., \& Metrick, A. (2003). Corporate governance and equity prices. The Quarterly Journal of Economics, 118, 107-155.

Gul, F. A., \& Leung S. (2004). Board leadership, outside directors expertise and voluntary corporate disclosures. Journal of Accounting \& Public Policy, 23(5), 351-379.

Hair, J., Anderson, R., Tatham, R., \& Black, W. (1998). Multivariate data analysis (5th Ed.). New Jersey: Prentice Hall.

Haniffa, R. M., \& Cooke, T. E. (2002). Culture, corporate governance and disclosure in Malaysian Corporations. Abacus, 38(3), 317-349.

Haniffa, R. M., \& Hudaib, M. (2007). Locating audit expectations gap within a cultural context: The case of Saudi Arabia, Journal of International Accounting, Auditing \& Taxation, 16(2), 179-206.

Healy, P., \& Palepu, K. (2001). Information asymmetry, corporate disclosure and the capital markets: A review of the empirical disclosure literature. Journal of Accounting \& Economics, 31, 405-440.

Ho, S. M., \& Wong, K. S. (2001). A study of the relationship between corporate governance structures and the extent of voluntary disclosure. Journal of Accounting, Auditing \& Taxation, 10(1), 139-156.

Hunziker, S. (2014). Internal control disclosure and agency costs - evidence from Swiss listed non-financial companies. IFZ [Working Paper No0024/2014]. Institute of Financial Services Zug IFZ, Lucerne University of Applied Sciences, Switzerland.

Jensen, M. C. (1993). The modern industrial revolution, exit, and the failure of internal control systems. Journal of Applied Corporate Finance, 22(1), 43-58.

Jensen, M. C., \& Meckling, W. H. (1976). Theory of the firm: Managerial behaviour, agency costs and ownership structure. Journal of Financial Economics, 3, 305-360.

Jouirou, M., \& Chenguel, M. B. (2014). The determinants of voluntary disclosure in Tunisia: A study of the firms listed in the Tunisian Stock Exchange. Journal of Business \& Management Research, 4, 86-97.

Kateb, I. (2012). An analysis of the determinants of voluntary structural capital disclosure by listed French companies. International Journal of Business\& Management, 7(11), 95-110.

Kelton, A. S., \& Yang, Y. (2008). The impact of corporate governance on internet financial reporting. Journal of Accounting \& Public Policy, 27, 62-87.

Lakhal, F. (2006). Les mécanismes de gouvernement d'entreprise et la publication volontaire des résultats en France. ComptabilitéContrôle-Audit, 2, 69-92.

Lanzana, A. (2004). Relaçâo entre o disclosure $e$ governança corporativa das empresas brasileiras (Tese de Mestrado). Universidade de São Paulo, SP, Brasil.

Lemos, K., Rodrigues, L. L., \& Ariza, L. (2009). Determinantes do nível de divulgação de informação sobre instrumentos derivados: Evidência empírica no mercado de capitais português. Polytechnical Studies Review, 7(12), 145-175.

Leung, S., \& Horwitz, B. (2004). Director ownership and voluntary segment disclosure: Hong Kong evidence. Journal of International Financial Management\& Accounting, 15(3), 235260.

Li, H., \& Qi, A. (2008). Impact of corporate governance on voluntary disclosure in Chinese listed companies. Corporate Ownership \& Control, 5(2), 360-366.

Lokman, N., Mula J. M., \& Cotter, J. (2014). Importance of corporate governance quality and 
voluntary disclosures of corporate governance information in listed Malaysian family controlled businesses. International Journal of Sustainable Development \& World Policy, 3(1), 1-24.

Lopes, P., \& Rodrigues, L. (2007). Accounting for financial instruments: An analysis of the determinants of disclosure in the Portuguese Stock Exchange. International Journal Accounting, 42(1), 25-56.

Macagnan, C. B. (2009). Evidenciação Voluntária: Fatores explicativos da extensão da informação sobre recursos intangíveis. Revista Contabilidade\& Finanças, 2(50), 46-61.

Mallin, C., \& Ow-Yong, K. (2012). Factors influencing corporate governance disclosures: Evidence from alternative investment market (aim) companies in the UK. The European Journal of Finance, 18(6), 515-533.

Mangena, M., Tauringana V. (2007). Disclosure, corporate governance and foreign share ownership on the Zimbabwe Stock Exchange. Journal of International Financial Management\& Accounting, 18(2), 53-85.

Marôco, J. (2007). Análise estatística com utilização do SPSS (3 $3^{\mathrm{a}}$ ed.). Lisboa: Ediçóes Sílabo.

Nagar, V., Nanda D., \& Wisocki, P. (2003). Discretionary disclosure and stock-based incentives. Journal of Accounting \& Economics, 34(1-3), 283-309.

Nekhili, M., Hussainey, K., Cheffi, W., Chtioui, T., \& Tchakoute-Tchuigoua, H. (2016). R\&D narrative disclosure, corporate governance and market value: Evidence from France. Journal of Applied Business Research, 32(1), 111-128.

Ntim, C., Opong, K., Danbolt, J., \& Thomas, D. (2012). Voluntary corporate governance disclosures by post-apartheid South African corporations. Journal of Applied Accounting Research, 13(2), 122-144.
OECD (1999). Principles of Corporate Governance. Paris: OECD Publications.

Oliveira, L., Rodrigues, L. L., \& Craig, R. (2006). Firm-specific determinants of intangibles reporting: Evidence from the Portuguese Stock Market. Journal of Human Resource Costing Accounting, 1O(1), 11-33.

Oliveira, L., Rodrigues, L. L., \& Craig, R. (2013). Stakeholder theory and the voluntary disclosure of intellectual capital information. Caspian Journal of Applied Sciences Research, 2(3), 75-93.

Regulamento da CMVM n.o 4/2013 (2013). Governo das sociedades cotadas - Lisboa. Retrieved from http://www.cmvm.pt/pt/ Legislacao/Legislacaonacional/Regulamentos/ Pages/Reg_2013_04.aspx

Rodrigues, L. L., Tejedo-Romero, F., \& Craig, R. (2017). Corporate governance and intellectual capital reporting in a period of financial crisis: Evidence from Portugal. International Journal of Disclosure and Governance, 14(1), 1-29.

Rouf, A. (2011). Corporate characteristics, governance attributes and the extent of voluntary disclosure in Bangladesh. African Journal of Business Management, 5(19), 7836-7845.

Samaha, K., Dahawy, K., Hussainey, K., \& Stapleton, P. (2012). The extent of corporate governance disclosure and its determinants in a developing market: The case of Egypt. Advances in Accounting, 28, 168-178.

Scholtz, H., \& Smit, A. R. (2015). Factors influencing corporate governance disclosure of companies listed on the alternative exchange (altx) in South Africa. South African Journal of Accounting Research, 29(1), 29-50.

Silveira, A. M. (2004). Governança corporativa e estrutura de propriedade: Determinantes e relação com o desempenho das empresas no Brasil (Tese de Doutorado). Universidade de São Paulo, SP, Brasil. 
Silveira, A. M., \& Barros, L. (2008). Determinantes da qualidade da governança corporativa das companhias abertas brasileiras. Revista Eletrônica de Administração-READ, 14(3), 512-540.

Soheilyfar, F., Tamimi, M., Ahmadi, M. R., \& Takhtaei, N. (2014). Disclosure quality and corporate governance: Evidence from Iran. Asian Journal of Finance \& Accounting, 6(2), 75-86.

Tsamenyi, M., Enninful-Adu, E., \& Onumah, J. (2007). Disclosure and corporate governance in developing countries: Evidence from Ghana. Managerial Auditing Journal, 22(3), 319-334.

Turrent, G., \& Rodríguez-Ariza, L. (2012). Corporate information transparency on the internet by listed companies in Spain (IBEX35) and Mexico (IPYC). International Journal of Digital Accounting Research, 12, 1-37.

Verrecchia, R. E. (1983). Discretionary disclosure. Journal of Accounting and Economics, 5, 179-194.

Verrecchia, R. E. (2001). Essays on disclosure. Journal of Accounting and Economics, 32, 97-180.

Wang, K., Sewon, O., \& Claiborne, M. C. (2008). Determinants and consequences of voluntary disclosure in an emerging market: Evidence from China. Journal of International Accounting, Auditing \& Taxation, 17, 14-30.

Watts, R., \& Zimmerman J. (1986), Positive accounting theory. NJ: Prentice Hall.

Webb, K. A., Cahan, S. F., \& Sun, J. (2008). The effect of globalization and legal environment on voluntary disclosure. The International Journal of Accounting, 43, 219-245.

Xiao, H., \& Yuan J. (2007). Ownership structure, board composition and corporate voluntary disclosure: Evidence from listed companies in China. Managerial Auditing Journal, 22(6), 604619.

Yermack, D. (1996). Higher market valuation of companies with a small board of directors. Journal of Financial Economics, 40, 185-211.

Yuen, D. C. Y., Liu, M., Zhang, X., \& Lu, C. (2009). A case study of voluntary disclosure by Chinese enterprises. Asian Journal of Finance \& Accounting, 1(2), 118-145. 


\section{Appendix 1 - Sample selection}

\begin{tabular}{lcccccccc}
\hline Description & $\mathbf{2 0 0 5}$ & $\mathbf{2 0 0 6}$ & $\mathbf{2 0 0 7}$ & $\mathbf{2 0 0 8}$ & $\mathbf{2 0 0 9}$ & $\mathbf{2 0 1 0}$ & $\mathbf{2 0 1 1}$ & Total \\
\hline $\begin{array}{l}\text { National law companies, listed on Euronext Lisbon at the end of } \\
\text { the year }\end{array}$ & 47 & 45 & 47 & 50 & 48 & 47 & 47 & $\mathbf{3 3 1}$ \\
$\begin{array}{l}\text { Companies excluded: } \\
\quad \text { Companies from the financial sector }\end{array}$ & 5 & 5 & 5 & 5 & 5 & 4 & 4 & $\mathbf{3 3}$ \\
$\quad$ - Anonymous sports societies (SAD's) & 2 & 2 & 3 & 3 & 3 & 3 & 3 & $\mathbf{1 9}$ \\
$\quad$ - Companies with incomplete information & 6 & 3 & 2 & 2 & 1 & 1 & 1 & $\mathbf{1 6}$ \\
Final Sample (Number of observations) & 34 & 35 & 37 & 40 & 39 & 39 & 39 & 263 \\
\hline
\end{tabular}

\section{Appendix 2 - CGD Items}

\begin{tabular}{|c|c|c|}
\hline N.o & Corporate Governance Items & Classif. \\
\hline \multicolumn{3}{|c|}{ A. Board of Director and Management Structures [BDMS] } \\
\hline 1. & $\begin{array}{l}\text { Organizational charts or functional maps relating to the division of powers between the various governing } \\
\text { bodies }\end{array}$ & {$[0,1]$} \\
\hline 2 & Identification and composition of the board - Chairman & {$[0,1]$} \\
\hline 3 & Identification and composition of the board - CEO & {$[0,1, \mathrm{~N} / \mathrm{A}]$} \\
\hline 4 & Identification and composition of the board - Executive Directors & {$[0,1]$} \\
\hline 5 & Identification and composition of the board - Non-Executive Directors & {$[0,1, \mathrm{~N} / \mathrm{A}]$} \\
\hline 6 & Identification and composition of the board - Independent Directors & {$[0,1, \mathrm{~N} / \mathrm{A}]$} \\
\hline 7 & Number of board meetings & {$[0,1]$} \\
\hline 8 & Role and functions of the board & {$[0,1]$} \\
\hline 9 & Policy on the rotation of responsibilities of the board & {$[0,1, \mathrm{~N} / \mathrm{A}]$} \\
\hline 10 & Explicit description of the conditions that determine the independence of board members & {$[0,1, \mathrm{~N} / \mathrm{A}]$} \\
\hline 11 & Date of $1^{\text {st }}$ appointment of board members & {$[0,1]$} \\
\hline 12 & Duration of directors' contracts & {$[0,1]$} \\
\hline 13 & Professional qualifications of board members & {$[0,1]$} \\
\hline 14 & Professional activities carried out by board members in the last 5 years & {$[0,1]$} \\
\hline 15 & Duties performed in other companies by board members, namely in companies of the same group & {$[0,1]$} \\
\hline 16 & Description of the activities carried out by non-executive directors & {$[0,1, \mathrm{~N} / \mathrm{A}]$} \\
\hline 17 & Individual remuneration of board members by year, including fixed and variable remuneration & {$[0,1]$} \\
\hline 18 & Is there an executive committee? & {$[0,1]$} \\
\hline 19 & Composition of the executive committee, including names, if applicable & {$[0,1, \mathrm{~N} / \mathrm{A}]$} \\
\hline 20 & Number of meetings of the executive committee, if applicable & {$[0,1, \mathrm{~N} / \mathrm{A}]$} \\
\hline 21 & Responsibilities divided between the board and the executive committee, if applicable & {$[0,1, \mathrm{~N} / \mathrm{A}]$} \\
\hline 22 & Performance evaluation criteria for executive directors & {$[0,1, \mathrm{~N} / \mathrm{A}]$} \\
\hline 23 & Corporate body responsible for disclosing privileged information and other communications to the market & {$[0,1, \mathrm{~N} / \mathrm{A}]$} \\
\hline 24 & Corporate body responsible for evaluating executive director performance & {$[0,1, \mathrm{~N} / \mathrm{A}]$} \\
\hline 25 & $\begin{array}{l}\text { Description of the agreements with Management or Other Officers which stipulate Compensation in the event } \\
\text { of Resignation, Unfair Dismissal or Termination of the Employment Relationship, following a Change in } \\
\text { Control }\end{array}$ & {$[0,1, \mathrm{~N} / \mathrm{A}]$} \\
\hline 26 & Rotation of the board members due to financial matters & {$[0,1, \mathrm{~N} / \mathrm{A}]$} \\
\hline
\end{tabular}




\begin{tabular}{|c|c|c|}
\hline N.o & Corporate Governance Items & Classif. \\
\hline \multicolumn{3}{|c|}{ B. Specialized Committees [SC] } \\
\hline 27 & Is there a remuneration committee? & {$[0,1]$} \\
\hline 28 & Remuneration committee composition, including names, if applicable & {$[0,1, \mathrm{~N} / \mathrm{A}]$} \\
\hline 29 & Identification of the remuneration committee chairman & {$[0,1, \mathrm{~N} / \mathrm{A}]$} \\
\hline 30 & Number of meetings of the remuneration committee, if applicable & {$[0,1, \mathrm{~N} / \mathrm{A}]$} \\
\hline 31 & Role and functions of the remuneration committee, if applicable & {$[0,1, \mathrm{~N} / \mathrm{A}]$} \\
\hline 32 & Description of the remuneration policy for executive directors & {$[0,1, \mathrm{~N} / \mathrm{A}]$} \\
\hline 33 & Is there a nomination committee? & {$[0,1]$} \\
\hline 34 & Composition of the nomination committee, including names, if applicable & {$[0,1, \mathrm{~N} / \mathrm{A}]$} \\
\hline 35 & Identification of the nomination committee chairman & {$[0,1, \mathrm{~N} / \mathrm{A}]$} \\
\hline 36 & Number of meetings of the nomination committee, if applicable & {$[0,1, N / A]$} \\
\hline 37 & Role and functions of the nomination committee, if applicable & {$[0,1, \mathrm{~N} / \mathrm{A}]$} \\
\hline 38 & Rules applicable to the appointment and replacement of board members, if applicable & {$[0,1, \mathrm{~N} / \mathrm{A}]$} \\
\hline 39 & Rules applicable to the appointment and replacement of audit committee members, if applicable & {$[0,1, \mathrm{~N} / \mathrm{A}]$} \\
\hline \multicolumn{3}{|c|}{ C. Audit and Risk Management [ARM] } \\
\hline 40 & Is there an audit committee? & {$[0,1, \mathrm{~N} / \mathrm{A}]$} \\
\hline 41 & Composition of the audit committee, including names, if applicable & {$[0,1, \mathrm{~N} / \mathrm{A}]$} \\
\hline 42 & Identification of the nomination committee chairman & {$[0,1, \mathrm{~N} / \mathrm{A}]$} \\
\hline 43 & Number of meetings of the audit committee, if applicable & {$[0,1, \mathrm{~N} / \mathrm{A}]$} \\
\hline 44 & Role and functions of the audit committee, if applicable & {$[0,1, \mathrm{~N} / \mathrm{A}]$} \\
\hline 45 & Description of the tasks of the audit committee, if applicable & {$[0,1, \mathrm{~N} / \mathrm{A}]$} \\
\hline 46 & Is there a risk management committee? & {$[0,1]$} \\
\hline 47 & Main economic, financial and legal risks that the company is exposed to when performing its activities & {$[0,1]$} \\
\hline 48 & Impact and likelihood of occurrence of each of the potential risks & {$[0,1]$} \\
\hline 49 & Description of the risk management measures implemented and their effectiveness & {$[0,1]$} \\
\hline 50 & Evaluation of the internal control and risk management system implemented & {$[0,1, \mathrm{~N} / \mathrm{A}]$} \\
\hline 51 & Term of office of the external auditor & {$[0,1]$} \\
\hline 52 & Total amount of fees paid to the external auditor & {$[0,1]$} \\
\hline 53 & Total amount paid to external auditor for services other than the legal review of accounts & {$[0,1, \mathrm{~N} / \mathrm{A}]$} \\
\hline 54 & The external auditor rotation period is indicated & {$[0,1]$} \\
\hline 55 & The supervisory body entrusted with the independence and integrity of the external auditor is indicated & {$[0,1]$} \\
\hline \multicolumn{3}{|c|}{ D. Ownership Structure [OS] } \\
\hline 56 & Percentage of shares owned by majority shareholders & {$[0,1]$} \\
\hline 57 & Number of shares owned by board members, if applicable & {$[0,1, \mathrm{~N} / \mathrm{A}]$} \\
\hline 58 & Own shares held by the company, if applicable & {$[0,1, \mathrm{~N} / \mathrm{A}]$} \\
\hline 59 & Measures adopted to prevent the success of takeover bids & {$[0,1, \mathrm{~N} / \mathrm{A}]$} \\
\hline 60 & Business and operations between the company and board members & {$[0,1, \mathrm{~N} / \mathrm{A}]$} \\
\hline 61 & Voting rights and rules on the exercising of voting rights & {$[0,1, \mathrm{~N} / \mathrm{A}]$} \\
\hline 62 & Availability of the preparatory information for general meetings & {$[0,1]$} \\
\hline 63 & $\begin{array}{l}\text { Availability of information concerning the last general meeting: date, the resolutions passed and the voting } \\
\text { results }\end{array}$ & {$[0,1]$} \\
\hline \multicolumn{3}{|c|}{ E. Compliance and Corporate Responsibility [CCR] } \\
\hline 64 & Is there a statement of compliance with the CMVM recommendations regarding corporate governance & {$[0,1]$} \\
\hline 65 & The company explains why it doesn't adopt the corporate governance recommendations & {$[0,1]$} \\
\hline 66 & An overall assessment is made on the degree of adoption of recommendations & {$[0,1]$} \\
\hline
\end{tabular}




\begin{tabular}{|c|c|c|}
\hline N.o & Corporate Governance Items & Classif. \\
\hline 67 & $\begin{array}{l}\text { Identification of the corporate body responsible for evaluating the adopted corporate governance system and } \\
\text { for verifying its effectiveness }\end{array}$ & {$[0,1, \mathrm{~N} / \mathrm{A}]$} \\
\hline 68 & There is a code of ethics, approved by the board of directors & {$[0,1]$} \\
\hline 69 & Disclosure of the code of ethics and its implementation program in the annual report & {$[0,1, \mathrm{~N} / \mathrm{A}]$} \\
\hline 70 & Disclosure of the whistleblowing policy for irregularities & {$[0,1, N / A]$} \\
\hline 71 & Signal of compliance with environmental legislation & {$[0,1, N / A]$} \\
\hline 72 & Certification for management quality & {$[0,1]$} \\
\hline 73 & Programs for management skills and continuous training of employees & {$[0,1]$} \\
\hline \multicolumn{3}{|c|}{ F. Financial Transparency [FT] } \\
\hline 74 & Financial and operating results in the last three years & {$[0,1]$} \\
\hline 75 & Market capitalization at the end of the year & {$[0,1]$} \\
\hline 76 & Management's statement of responsibility for financial reporting & {$[0,1]$} \\
\hline 77 & Statement of compliance with international financial reporting standards (IFRS) & {$[0,1]$} \\
\hline 78 & The principal accounting policies adopted in preparing the financial statements & {$[0,1]$} \\
\hline 79 & Judgments and estimates adopted in the preparation of the annual financial statements & {$[0,1]$} \\
\hline 80 & Nature, type and elements of related-party transactions & {$[0,1, \mathrm{~N} / \mathrm{A}]$} \\
\hline 81 & Procedures and criteria for preliminary valuation of transactions between related parties & {$[0,1, \mathrm{~N} / \mathrm{A}]$} \\
\hline 82 & Description of the policy changes, estimates and errors & {$[0,1, N / A]$} \\
\hline
\end{tabular}

\section{Notes}

1 Article derived from the doctoral thesis: “Divulgação de Informação sobre o Governo das Sociedades: Extensão e Determinantes” defended by Vera Cunha, orientated by Prof. Dr. Lúcia Lima Rodrigues, Escola de Economia e Gestão, Universidade do Minho, Portugal, 2015.

\section{About the authors: \\ 1. Vera Cunha, PhD in Accounting, Universidade do Minho, Portugal. E-mail: vera.cunha@estgoh.ipc.pt ORCID \\ (iD) 0000-0002-8608-6735}

2. Lúcia Lima Rodrigues, PhD in Corporate Sciences, Universidade do Minho, Portugal.

E-mail: lrodrigues@eeg.uminho.pt

ORCID

(iD) 0000-0003-0859-0853

\section{Contribution of each author:}

\begin{tabular}{lcc}
\hline Contribution & Vera Cunha & Lúcia Lima Rodrigues \\
\hline 1. Definition of research problem & $\sqrt{ }$ & $\sqrt{ }$ \\
2. Development of hypotheses or research questions (empirical studies) & $\sqrt{ }$ \\
3. Development of theoretical propositions (theoretical work) & $\sqrt{ }$ \\
4. Theoretical foundation/Literature review & $\sqrt{ }$ \\
5. Definition of methodological procedures & $\sqrt{ }$ \\
6. Data collection & $\sqrt{ }$ \\
7. Statistical analysis & $\sqrt{ }$ \\
8. Analysis and interpretation of data & $\sqrt{ }$ \\
9. Critical revision of the manuscript & $\sqrt{ }$ \\
10. Manuscript writing & $\sqrt{ }$ \\
11. Other supervision & \\
\hline
\end{tabular}

